\title{
EFEKTIVITAS KOMPOSISI PROBIOTIK YANG BERBEDA PADA TEKNOLOGI AKUAPONIK UNTUK MENGOPTIMALKAN LAJU PERTUMBUHAN DAN KONVERSI PAKAN IKAN GABUS (Channa sp.)
}

\section{THE EFFECTIVENESS OF DIFFERENT PROBIOTIC COMPOSITION IN AQUAPONIC TECHNOLOGY TO OPTIMIZE GROWTH RATE AND CONVERSION FEED OF SNAKEHEAD FISH (Channa sp.)}

Fazril Saputra $^{1 *}$, Muhammad Agam Thahir ${ }^{2}$, Mahendra' ${ }^{1}$, Yusran Ibrahim¹, Muhammad Arif Nasution ${ }^{3}$, Teuku Reza Efianda ${ }^{4}$

${ }^{1}$ Program Studi Akuakultur, Fakultas Perikanan dan Ilmu Kelautan, Universitas Teuku Umar, Aceh Barat

${ }^{2}$ Program Studi Perikanan, Fakultas Perikanan dan Ilmu Kelautan, Universitas Teuku Umar, Aceh Barat

${ }^{3}$ Program Studi Sumber Daya Akuatik, Fakultas Perikanan dan Ilmu Kelautan, Universitas Teuku Umar, Aceh Barat

${ }^{4}$ Program Studi Perikanan, Politeknik Indonesia Venezuela, Aceh Besar

*Korespondensi: fazrilsaputra@utu.ac.id

\begin{abstract}
Snakehead (Channa sp.) was one of the superior freshwater fish species native to Indonesia that has been successfully domesticated. The increasing demand for snakehead fish on the market has resulted in the addition of cultivated land and water use. Aquaponics technology was a combination of fish farming and plants that grow without soil media. The aim of this research was to determine the best composition of probiotics that can be used in aquaponic technology to optimize growth rate and feed conversion of snakehead fish (Channa sp.). This research used an experimental method. The experimental design used was a completely randomized design with four probiotic combination treatments and each treatment was repeated three times. The results showed that awarding of different probiotic compositions in the aquaponic system resulted in a spesific growth rate that was not significantly $(P>0.05)$ different between treatments. The highest value of spesific growth rate were in the treatment of probiotic composition of Lactobacillus casei and Saccharomyces cerevisiae with a value of $4.11 \%$ / day. Awarding of different probiotic compositions in the aquaponic system results in significantly $(P<0.05)$ different feed conversion ratio values. The best feed conversion ratio values were in the treatment of probiotic composition of Lactobacillus casei and Saccharomyces cerevisiae with a value of 1.78. The conclusion of this study was the composition of probiotic Lactobacillus casei and Saccharomyces cerevisiae was the best probiotic composition to increase the spesific growth rate and feed conversion ratio of snakehead fish.
\end{abstract}

Keywords: Freshwater fish, Lactobacillus casei, Saccharomyces cerevisiae, Species native

\section{Pendahuluan}

Ikan gabus (Channa sp.) merupakan salah satu spesies ikan air tawar asli Indonesia yang telah berhasil didomestikasi. Ikan ini dapat hidup dalam berbagai bentuk wadah budidaya sehingga mudah untuk dibudidayakan (Saputra dan 
Mahendra, 2019). Ikan gabus banyak diminati di pasaran karena mempunyai keunggulan dibandingkan dengan ikan lain yaitu ikan gabus memiliki daging yang tebal dan cita rasa khas. Ikan ini merupakan jenis ikan konsumsi yang memiliki prospek menjanjikan dipasaran. Ikan gabus segar dihargai dengan harga Rp 30.000 ribu/kg hingga Rp 60.000 ribu/kg untuk ukuran konsumsi (BPBATM, 2014). Tingginya harga penjualan ikan gabus di pasaran mengakibatkan para pembudidaya melakukan berbagai cara agar laju pertumbuhan dan konversi pakan hasil budidaya ikan gabus meningkat. Salah satu untuk meningkatkan laju pertumbuhan dan konversi pakan hasil budidaya ikan gabus adalah dengan memberikan pakan yang berkualitas.

Pakan merupakan faktor penentu pertumbuhan dan pengeluaran terbesar dalam total biaya produksi budidaya (60-70 \%) (Pangaribuan et al., 2009). Tingginya harga pakan dan kualitas nutrisi yang rendah merupakan hambatan dalam usaha budidaya, oleh karena itu dibutuhkan bahan tambahan yang dapat meningkatkan laju pertumbuhan harian dan rasio konversi pakan sehingga dapat mengurangi biaya produksi pakan, salah satunya dengan memberikan probiotik.

Probiotik adalah mikroorganisme hidup yang memberi manfaat kesehatan pada inang ketika diberikan dalam jumlah yang memadai, selain itu probiotik juga dapat menjaga kualitas air hasil budidaya (Mansyur dan Tangko, 2008). Beberapa penelitian sebelumnya menyebutkan bahwa aplikasi probiotik mempunyai peranan dalam perbaikan kualitas air, peningkatan biosekuriti, peningkatan produktivitas, peningkatan efisiensi pakan serta penurunan biaya produksi melalui penurunan biaya pakan (Avnimelech and Kochba, 2009; Kuhn et al., 2009; Lu et al., 2019). Selama ini banyak penelitian yang menyebutkan penggunaan probiotik untuk budidaya ikan (Arief et al., 2014; Anwar et al., 2016; Anis dan Hariani, 2019), namun belum ada penelitian yang menyebutkan probiotik terbaik yang dapat digunakan pada teknologi akuaponik. Teknologi akuaponik adalah kombinasi dari akuakultur (budidaya ikan) dan hidroponik (tanaman yang tumbuh tanpa tanah). Sistem ini adalah sebuah sistem daur ulang air tawar tertutup antara ikan dan tanaman. Limbah yang dihasilkan oleh ikan menjadi nutrisi bagi tanaman setelah proses nitrifikasi (Nicolae et al., 2015). Berdasarkan penjelasan di atas, perlu dilakukan penelitian untuk mengetahui komposisi probiotik terbaik yang dapat digunakan pada teknologi akuaponik untuk optimasi laju pertumbuhan dan konversi pakan ikan gabus (Channa sp.).

\section{Metode Penelitian}

\section{Waktu dan tempat}

Penelitian ini dilaksanakan pada tanggal 1 Oktober hingga 31 Desember 2019 di Hatchery Mini Seunebok Fakultas Perikanan dan Ilmu Kelautan Universitas Teuku Umar. Analisis laboratorium dilaksanakan di Laboratorium Terpadu Universitas Teuku Umar dan Laboratorium Balai Perikanan Budidaya Air Payau Ujung Batee. 


\section{Alat dan bahan}

Alat-alat yang digunakan dalam penelitian ini meliputi: wadah akuarium tempat pemeliharaan ikan, pompa air, selang, pipa PVC 2,5 inci, jaring, timbangan digital, gelas ukur, $\mathrm{pH}$ meter, termometer, DO meter, dan penggaris. Bahan-bahan yang digunakan meliputi: benih ikan gabus, rockwool, tanaman kangkung, dan probiotik.

Probiotik yang digunakan pada penelitian ini merupakan komposisi probiotik komersial terbaik dari penelitian-penelitian sebelumnya yang telah diuji pada ikan namun belum diuji pada teknologi akuaponik. Komposisi-komposisi probiotikprobiotik tersebut antara: menurut Arief (2014) Lactobacillus sp., Acetobacter, Rhodobacter, yeast; menurut Zega et al., (2018), Bacillus sp., Nitrobacter sp., dan Nitrosomonas sp.; menurut Anis dan Hariani (2019), Lactobacillus casei dan Saccharomyces cerevisiae. Pemilihan tanaman kangkung dikarenakan hasil penelitian sebelumnya menyebutkan kangkung merupakan tanaman yang paling baik untuk digunakan pada teknologi akuaponik (Damanik et al., 2018; Nazlia dan Zulfiadi, 2018).

\section{Rancangan percobaan}

Penelitian ini dilakukan dengan metode eksperimental. Rancangan percobaan yang digunakan adalah rancangan acak lengkap (RAL) dengan 4 perlakuan dan masing-masing perlakuan diulang sebanyak 3 kali (Tabel 1).

Tabel 1. Rancangan perlakuan komposisi-komposisi probiotik

\begin{tabular}{|c|c|c|}
\hline $\begin{array}{l}\mathrm{N} \\
\mathrm{O}\end{array}$ & Kode & Keterangan \\
\hline 1 & P01 & Perlakuan tanpa pemberian komposisi probiotik/kontrol ulangan 1 \\
\hline 2 & $\mathrm{P} 02$ & Perlakuan tanpa pemberian komposisi probiotik/kontrol ulangan 2 \\
\hline 3 & $\mathrm{P} 03$ & Perlakuan tanpa pemberian komposisi probiotik/kontrol ulangan 3 \\
\hline 4 & $\mathrm{P} 11$ & $\begin{array}{l}\text { Komposisi probiotik Bacillus sp., Nitrobacter sp., dan } \\
\text { Nitrosomonas sp. ulangan } 1\end{array}$ \\
\hline 5 & P12 & $\begin{array}{l}\text { Komposisi probiotik Bacillus sp., Nitrobacter sp., dan } \\
\text { Nitrosomonas sp. ulangan } 2\end{array}$ \\
\hline 6 & P13 & $\begin{array}{l}\text { Komposisi probiotik Bacillus sp., Nitrobacter sp., dan } \\
\text { Nitrosomonas sp. ulangan } 3\end{array}$ \\
\hline 7 & $\mathrm{P} 21$ & $\begin{array}{l}\text { Komposisi probiotik Lactobacillus casei dan Saccharomyces } \\
\text { cerevisiae ulangan } 1\end{array}$ \\
\hline 8 & $\mathrm{P} 22$ & $\begin{array}{l}\text { Komposisi probiotik Lactobacillus casei dan Saccharomyces } \\
\text { cerevisiae ulangan } 2\end{array}$ \\
\hline 9 & $\mathrm{P} 23$ & $\begin{array}{l}\text { Komposisi probiotik Lactobacillus casei dan Saccharomyces } \\
\text { cerevisiae ulangan } 3\end{array}$ \\
\hline 10 & P31 & $\begin{array}{l}\text { Komposisi probiotik Lactobacillus sp., Acetobacter, Rhodobacter } \\
\text { sp., yeast ulangan } 1\end{array}$ \\
\hline
\end{tabular}






\section{Persiapan wadah pemeliharaan}

Wadah yang digunakan berupa akuarium dengan ukuran $50 \times 30 \times 30 \mathrm{~cm}^{3}$ sebanyak 12 unit yang dibersihkan dengan sabun kemudian didesinfeksi dengan kalium permanganat $(\mathrm{PK})$ dengan dosis $15 \mathrm{mg} / \mathrm{L}$ selama tiga hari. Setelah itu akuarium dibilas dan dibiarkan kering. Setelah proses desinfeksi selesai, selanjutnya akuarium diisi dengan air sebanyak $40 \mathrm{~L}$. Benih ikan gabus yang digunakan berukuran 4-5 $\mathrm{cm}$. Sebelum ditebar pada media pemeliharaan benih gabus diaklimatisasi terlebih dahulu agar suhu air media selama pengangkutan benih dengan air media pada wadah pemeliharaan sama. Benih ikan gabus kemudian dimasukkan ke dalam bak pemeliharaan dengan padat tebar 10 ekor ikan gabus.

\section{Persiapan instalasi teknologi akuaponik sistem sumbu dan penyemaian kangkung}

Persiapan instalasi dimulai dari merancang teknologi akuaponik dengan sistem wick/sumbu yang terdiri bahan dan alat yang dapat dilihat pada Gambar 1 dibawah ini. Tanaman kangkung harus disemai terlebih dahulu pada media rockwool, setelah tumbuh baru dipindahkan ke dalam netpot. Waktu persemaian kurang lebih 12-14 hari. Jumlah tanaman kangkung yang digunakan adalah 9 batang/akuarium.

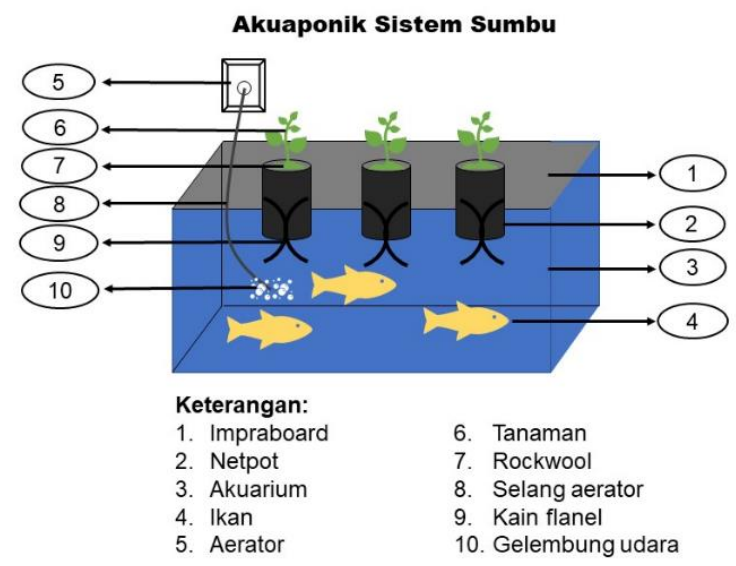

Gambar 1. Modifikasi sketsa instalasi teknologi akuaponik sistem wick/sumbu

\section{Pemeliharaan benih ikan gabus dan pemberian komposisi probiotik ke dalam wadah budidaya}

Pemeliharaan ikan gabus dilakukan dengan pemberian pakan alami berupa cacing sutra dengan kandungan protein 57\% yang diberikan dua kali sehari pada pukul 08.00 WIB dan 16.00 WIB. Pakan yang diberikan sejumlah $10 \%$ dari berat tubuh ikan. Satu minggu sebelum pemeliharaan ikan gabus dilakukan penambah komposisi-komposisi probiotik dalam media budidaya sebanyak $0,25 \mathrm{ml}$ probiotik 
/L air. Pemberian komposisi-komposisi probiotik selanjutnya dilakukan setiap satu minggu sekali dalam media pemeliharaan.

\section{Parameter uji}

Parameter yang diuji selama penelitian meliputi laju pertumbuhan harian (LPH) dan rasio konversi pakan (RKP). Laju pertumbuhan harian adalah perubahan ikan dalam berat, ukuran, maupun volume seiring dengan perubahan waktu ketika ikan dibudidayakan di dalam wadah budidaya. Rasio konversi pakan adalah suatu ukuran yang menyatakan ratio jumlah pakan yang dibutuhkan untuk menghasilkan $1 \mathrm{~kg}$ ikan yang dibudidayakan dalam wadah budidaya. Bobot ikan untuk laju pertumbuhan harian dan rasio konversi pakan diukur menggunakan timbangan digital dengan ketelitian berat 0,01 gram. Parameter kualitas air yang diukur meliputi suhu dan $\mathrm{pH}$. Pengukuran parameter ini dilakukan secara in situ. Pengukuran parameter suhu menggunakan termometer dan pengukuran parameter $\mathrm{pH}$ menggunakan $\mathrm{pH}$ meter. Parameter kualitas air ini diukur satu minggu sekali pada saat pagi, siang dan sore hari.

Laju pertumbuhan harian (LPH) ikan diamati dari awal hingga akhir penelitian. Laju pertumbuhan harian dihitung dengan rumus (Bai et al., 2010):

$$
\text { LPH }(\% / h a r i)=\frac{\operatorname{Ln} B t-\operatorname{Ln} B o}{t} \times 100
$$

Dimana:

LPH : laju pertumbuhan harian (\%/hari),

Bt : bobot rata-rata ikan pada akhir penelitian (gram),

Bo : bobot rata-rata ikan pada awal penelitian (gram),

$\mathrm{t} \quad$ : periode pemeliharaan (hari)

Rasio konversi pakan (RKP) dihitung dengan menggunakan rumus (Zonneveld et al., 1991):

$$
\mathrm{RKP}=\frac{F}{B t+B m-B o}
$$

Dimana :

RKP : rasio konversi pakan,

F : jumlah pakan (gram),

Bt : biomassa ikan pada saat akhir perlakuan (gram),

$\mathrm{Bm}$ : biomassa ikan yang mati saat perlakuan (gram),

Bo : biomassa ikan pada saat awal perlakuan (gram)

\section{Analisis data}

Data yang diperoleh ditabulasi dengan program MS. Office Excel 2010 dan diuji secara statistik satu arah (one way ANOVA) menggunakan program SPSS 16.0 pada selang kepercayaan $95 \%$. Perlakuan yang berbeda nyata akan diuji lanjut dengan uji Duncan untuk mengetahui perlakuan terbaik. Parameter laju pertumbuhan harian (LPH) dan rasio konversi pakan (RKP) disajikan dalam bentuk 
grafik sedangkan parameter kualitas air (suhu, $\mathrm{pH}$, dan oksigen terlarut) disajikan secara deskriptif.

\section{Hasil dan Pembahasan}

Hasil pengamatan pemberian komposisi probiotik yang berbeda pada teknologi akuaponik untuk optimalisasi laju pertumbuhan dan konversi pakan ikan gabus (Channa sp.) dapat dilihat pada grafik dan tabel dibawah ini. Gambar 2 menggambarkan tentang grafik laju pertumbuhan harian dan gambar 3 menggambarkan rasio konversi pakan sedangkan tabel 1 menggambarkan nilai parameter kualitas air benih ikan gabus yang diberikan pakan dengan komposisi probioti yang berbeda.

\section{Laju pertumbuhan harian (LPH)}

Hasil penelitian pemberian komposisi probiotik yang berbeda pada teknologi akuaponik terhadap laju pertumbuhan harian (LPH) ikan gabus (Channa sp.) disajikan pada Gambar 2. Laju pertumbuhan harian tertinggi terdapat pada perlakukan P2 dan laju pertumbuhan terendah terdapat pada perlakuan P0.

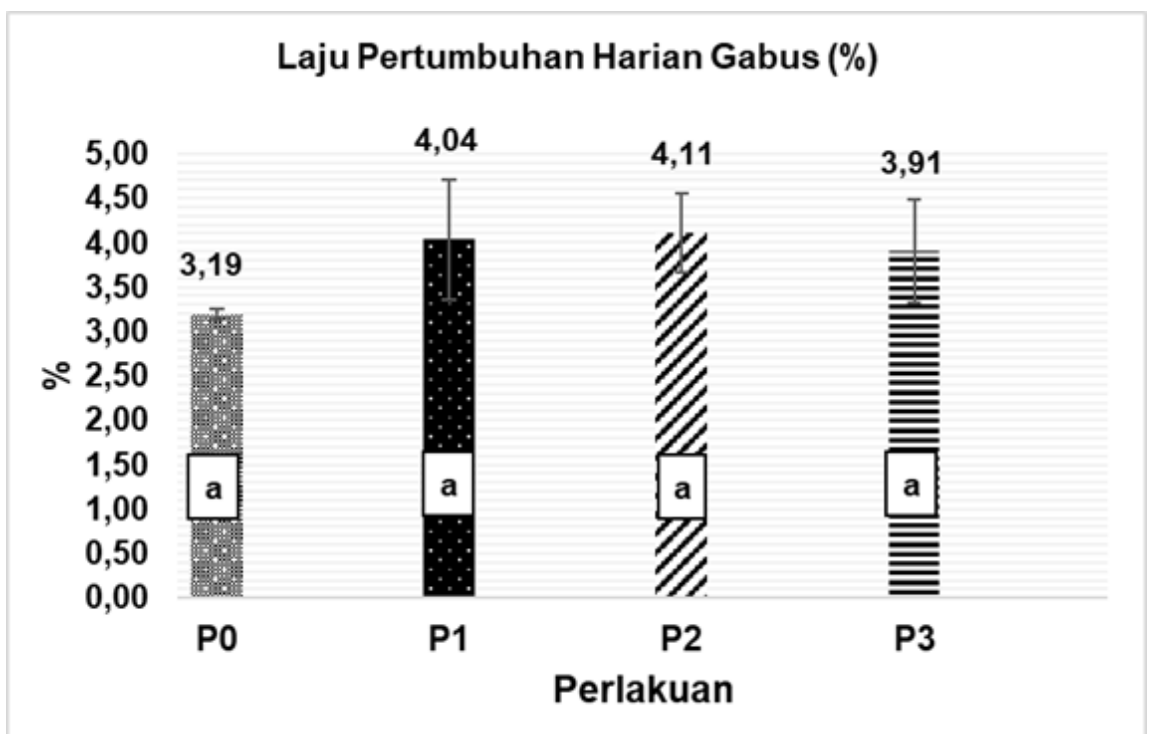

Gambar 2. Grafik laju pertumbuhan harian (\%/hari) benih ikan gabus (Channa

sp.)

P0: Kontrol/perlakuan tanpa pemberian komposisi probiotik,

P1: Komposisi probiotik Bacillus sp., Nitrobacter sp., dan Nitrosomonas sp.,

P2: Komposisi probiotik Lactobacillus casei dan Saccharomyces cerevisiae,

P3: Komposisi probiotik Lactobacillus sp., Acetobacter, Rhodobacter sp., yeast.

Huruf abjad kecil yang sama pada masing-masing gambar grafik menunjukkan hasil yang tidak berbeda nyata $(\mathrm{P}>0,05)$. 


\section{Rasio konversi pakan (RKP)}

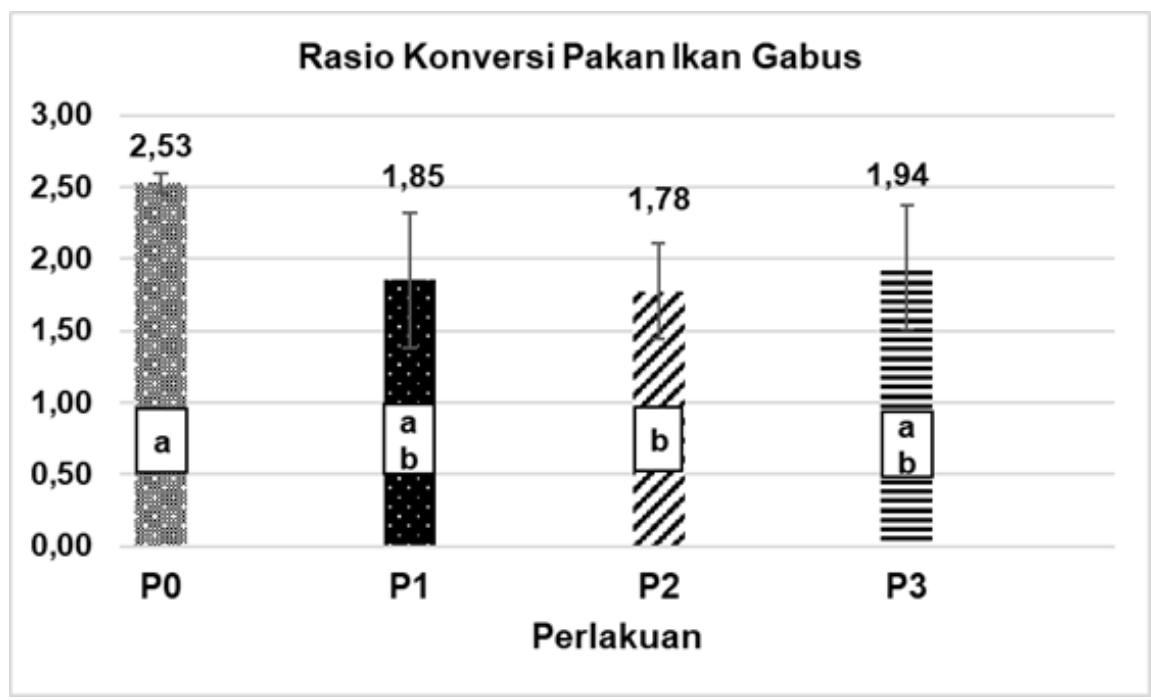

Gambar 3. Grafik rasio konversi pakan (RKP) benih ikan gabus (Channa sp.)

P0: Kontrol/perlakuan tanpa pemberian komposisi probiotik,

P1: Komposisi probiotik Bacillus sp., Nitrobacter sp., dan Nitrosomonas sp.,

P2: Komposisi probiotik Lactobacillus casei dan Saccharomyces cerevisiae,

P3: Komposisi probiotik Lactobacillus sp., Acetobacter, Rhodobacter sp., yeast.

Huruf abjad kecil yang berbeda pada masing-masing gambar grafik menunjukkan hasil yang berbeda nyata $(\mathrm{P}<0,05)$.

Hasil penelitian pemberian komposisi probiotik yang berbeda pada teknologi akuaponik terhadap rasio konversi pakan (RKP) ikan gabus (Channa sp.) disajikan pada Gambar 3. Rasio konversi pakan (RKP) terrendah terdapat pada perlakuan P2 dan tertinggi terdapat pada perlakukan $\mathrm{P} 0$.

\section{Parameter kualitas air}

Parameter kualitas air yang dilihat dalam penelitian ini ada 2 yaitu Suhu $\left({ }^{\circ} \mathrm{C}\right)$ dan $\mathrm{pH}$. Nilai pengukuran parameter kualitas air selama penelitian dapat dilihat pada Tabel 1 .

Tabel 1. Nilai parameter kualitas air

\begin{tabular}{lcccc}
\hline \multirow{2}{*}{ Parameter } & \multicolumn{4}{c}{ Perlakuan } \\
\cline { 2 - 5 } & P0 & P1 & P2 & P3 \\
\hline Suhu $\left({ }^{\circ} \mathrm{C}\right)$ & $27-28$ & $26-28$ & $27-28$ & $27-28$ \\
pH & $6,5-7,5$ & $6,5-7,5$ & $6,0-7,4$ & $6,3-7,5$ \\
\hline
\end{tabular}

Keterangan:

P0: Kontrol/perlakuan tanpa pemberian probiotik,

P1: Komposisi probiotik Bacillus sp., Nitrobacter sp., dan Nitrosomonas sp.,

P2: Komposisi probiotik Lactobacillus casei dan Saccharomyces cerevisiae,

P3: Komposisi probiotik Lactobacillus sp., Acetobacter, Rhodobacter sp., yeast. 


\section{Pembahasan}

Pemberian komposisi probiotik yang berbeda melalui media pemeliharaan pada teknologi akuaponik untuk laju pertumbuhan harian (LPH) ikan gabus (Channa sp.) menunjukkan hasil yang tidak berbeda nyata $(\mathrm{P}>0,05)$ antara perlakuan (lihat Gambar 2). Namun perlakuan P2 dengan penambahan komposisi probiotik Lactobacillus casei dan Saccharomyces cerevisiae didapatkan hasil pertumbuhan tertinggi dibandingkan dengan perlakuan lainnya. Nilai LPH pada perlakuan P2 mencapai 4,11 \%/ hari. Hal ini diduga karena penambahan komposisi probiotik Lactobacillus casei dan Saccharomyces cerevisiae ke dalam media pemeliharaan membuat sinergisme komposisi probiotik bekerja dalam saluran pencernaan dan meningkatkan daya cerna terhadap pakan sehingga memacu pertumbuhan ikan gabus. Hasil penelitian ini serupa dengan penelitian yang dilakukan oleh Hernandez et al. (2010), penambahan bakteri Lactobacillus casei pada ikan Poecilopsis gracilis menghasilkan kecenderungan nilai LPH sedikit lebih tinggi dibandingkan kontrol. Penelitian sebelumnya yaitu penambahan bakteri Lactobacillus melalui air dapat berpengaruh juga pada saluran pencernaan ikan. Bakteri Lactobacillus berfungsi meningkatkan daya cerna ikan terhadap pakan sehingga dapat memacu pertumbuhan ikan (Gatesoupe, 1999; Sugih, 2005; Zhou dan Wang, 2014). Selain itu terdapatnya khamir Saccharomyces cerevisiae pada komposisi probiotik juga meningkatkan pola makan dan kecernaan protein sehingga meningkatkan pertumbuhan ikan gabus. Hal ini sesuai dengan penelitian sebelumnya pada khamir Saccharomyces cerevisiae menunjukkan bahwa penambahan khamir Saccharomyces cerevisiae dapat meningkatkan pola makan dan kecernaan protein sehigga meningkatkan pertumbuhan dan efisiensi makanan (Wache et al., 2006; Boloki et al., 2011; Mohammadi et al., 2016). Rendahnya nilai LPH pada perlakuan P0 dibandingkan dengan perlakuan lainnya diduga karena tidak ada penambahan komposisi probiotik ke perlakuan P0 sehingga tidak meningkatkan pola makan dan kecernaan ikan gabus. Ini didukung oleh hasil penelitian Primashita et al. (2017), perlakuan tanpa penambahan probiotik (kontrol) pada sistem akuaponik menghasilkan nilai LPH yg lebih rendah dibandingkan dengan perlakuan penambahan probiotik.

Pemberian komposisi probiotik yang berbeda pada teknologi akuaponik untuk rasio konversi pakan (RKP) ikan gabus (Channa sp.) menunjukkan hasil yang berbeda-beda. Perlakuan P2 dengan penambahan komposisi probiotik P2 yaitu Lactobacillus casei dan Saccharomyces cerevisiae menghasilkan nilai yang berbeda nyata $(\mathrm{P}<0,05)$ dibandingkan dengan kontrol (lihat Gambar 3). Nilai RKP pada perlakuan P2 mencapai 1,78. Hal ini diduga karena pemberian perlakuan komposisi probiotik P2 melalui media pemeliharaan berpengaruh terhadap saluran pencernaan ikan gabus. Pemberian komposisi probiotik yaitu Lactobacillus casei dan Saccharomyces cerevisiae ke dalam melalui media pemeliharaan membuat komposisi probiotik masuk kedalam saluran pencernaan ikan sehingga dapat menekan bakteri patogen yang ada dalam usus sehingga membantu proses 
penyerapan makanan lebih cepat. Pemberian probiotik pada ikan gabus membuat pemanfaatkan pakan yang diberikan lebih optimal sehingga pakan tersebut terserap dan diubah menjadi daging (Agustin et al., 2014). Hasil penelitian ini serupa dengan hasil penelitian Sukoco et al. (2016), pemberian probiotik pada sistem akuaponik menghasilkan nilai FCR yg lebih rendah dibandingkan dengan pemberian tanpa probiotik/ kontrol. Selain itu penelitian sebelumnya menjelaskan bahwa probiotik (Lactobacillus sp.) yang diisolasi dari usus ikan mas dapat mengurangi RKP (Manoppo et al., 2019). Manoppo et al. (2019), juga menjelaskan bahwa probiotik (Lactobacillus sp.) yang diisolasi di organ usus ikan lele dan diberikan kepada ikan mas dapat mengurangi RKP. Probiotik yang diisolasi dari saluran pencernaan kerapu tikus juga dapat mengurangi nilai konversi pakan, meningkatkan pertumbuhan, retensi protein dan lemak (Marlida et al 2014). Rendahnya nilai RKP pada perlakuan P0 dibandingkan dengan perlakuan lainnya diduga karena tidak ada penambahan probiotik ke dalam perlakuan P0 sehingga tidak menekan bakteri patogen yang ada dalam usus ikan gabus dan hal ini menyebabkan proses penyerapan makanan tidak berlangsung lebih cepat. Hal ini didukung oleh penelitian Midhun et al. (2019); Mulyasari et al. (2016); Ling et al. (2018); Rahmawan et al. (2014); Hemaiswarya el al. (2013), penggunaan probiotik dalam akuakultur dapat meningkatkan pertumbuhan, kecernaan dan efisiensi pakan, nafsu makan, sistem kekebalan ikan, toleransi terhadap stres dan ketahanan terhadap patogen. Probiotik masuk ke dalam usus ikan kemudian membantu proses pencernaan sehingga pakan akan lebih efisien dimanfaatkan oleh ikan karena nutrisi pakan akan mudah terserap oleh tubuh ikan (Setiawati et al. 2013).

Nilai parameter kualitas air selama penelitian dapat dilihat pada Tabel 1. Nilai parameter kualitas air sangat menentukan keberhasilan penelitian pemberian komposisi probiotik yang berbeda pada teknologi akuaponik ini. Nilai parameter kualitas air selama penelitian secara umum masih layak untuk mendukung laju pertumbuhan dan konversi pakan benih ikan gabus (Channa sp.). Parameter yang diukur selama penelitian adalah parameter suhu dan $\mathrm{pH}$. Suhu merupakan parameter penting dalam kegiatan budidaya ikan karena mempengaruhi laju metabolisme ikan, proses biologis ikan, proses kimiawi, dan mempengaruhi parameter kualitas air lainnya. Parameter suhu pada penelitian ini masih dikatagorikan layak yaitu $26-28{ }^{\circ} \mathrm{C}$ (Courtenay \& Williams, 2004). Nilai pH air selama penelitian masih dalam pada kisaran yang layak untuk ikan gabus yaitu 6,06,5 (Jianguang et al. 1997). Penurunan nilai $\mathrm{pH}$ disebabkan peningkatan konsentrasi $\mathrm{CO}_{2}$ pada media pemeliharaan selama penelitian. Senyawa $\mathrm{CO}_{2}$ selama respirasi akan bereaksi dengan air sehingga menghasilkan asam karbonat $\left(\mathrm{H}_{2} \mathrm{CO}_{3}\right)$ yang dapat menurunkan pH air (William \& Robert, 1992).

\section{Kesimpulan dan Saran}

Pemberian komposisi probiotik lactobacillus casei dan saccharomyces cerevisiae melalui media pemeliharaan pada teknologi akuaponik berpengaruh nyata $(\mathrm{p}<0,05)$ terhadap rasio konversi pakan ikan gabus (clarias sp.) bila 
dibandingkan dengan kontrol. pemberian probiotik melalui media pemeliharaan pada teknologi akuaponik tidak berpengaruh nyata $(\mathrm{p}>0,05)$ terhadap laju pertumbuhan harian ikan gabus (clarias sp.) bila dibandingkan dengan kontrol, namun laju pertumbuhan harian tertinggi terdapat pada komposisi probiotik lactobacillus casei dan saccharomyces cerevisiae.

Perlunya suatu penelitian lanjutan mengenai penggunaan probiotik pada sistem akuaponik ikan gabus dan kangkung dengan skala produksi.

\section{Ucapan terimakasih}

Riset penulis dibiayai oleh LPPM dan Penjaminan Mutu, Universitas Teuku Umar, Program Penelitian Dosen Muda Tahun Anggaran 2019 dengan No. Kontrak 342/ UN59/ PT.01.03/ 2019 dan ucapan terima kasih kepada Program Studi Akuakultur, Fakultas Perikanan dan Ilmu Kelautan.

\section{Daftar pustaka}

Agustin R, Sasanti AD, Yulisman. 2014. Konversi pakan, laju pertumbuhan, kelangsungan hidup dan populasi bakteri benih ikan gabus (channa striata) yang diberi pakan dengan penambahan probiotik. Jurnal Akuakultur Rawa Indonesia 2(1): 55-66.

Anis MY dan Hariani D, 2019 Pemberian Pakan Komersial dengan Penambahan EM4 (Effective Microorganisme 4) untuk Meningkatkan Laju Pertumbuhan Lele (Clarias sp.). Jurnal Riset Biologi dan Aplikasinya 1(1): 1-10.

Anwar S, Arief M dan Agustono. 2016. Pengaruh Pemberian Probiotik Komersial Pada Pakan Terhadap Laju Pertumbuhan Dan Efisiensi Pakan Udang Vaname (Litopenaeus Vannamei). Journal of Aquaculture and Fish Health 5(2): 1-6

Arief M, Fitriani N dan Subekti S. 2014. Pengaruh Pemberian Probiotik Berbeda Pada Pakan Komersial Terhadap Pertumbuhan Dan Efisiensi Pakan Ikan Lele Sangkuriang (Clarias sp.). Jurnal Ilmiah Perikanan dan Kelautan 6(1): 4953.

Avnimelech Y and Kochba M. 2009. Evaluation of Nitrogen Uptake Excretion By Tilapia In Biofloc Tanks, Using 15N Tracing. Aquaculture 287: 163-168.

Balai Perikanan Budidaya Air Tawar Mandiangin. 2014. Naskah Akademik Ikan Gabus Haruan (Channa Striata Bloch 1793) Hasil Domestikasi. Mandiangin: Kementerian Kelautan Perikanan, Mandiangin.

Bai N, Zhang W, Mai K, Wang X, Xu W, dan Ma H. 2010. Effects of discontinuous administration of $\beta$-glucan and glycyrrhizin on the growth and immunity of white shrimp Litopenaeus vannamei. Aquaculture 306: 218-224.

Boloki ML, Jafaryan H, Faramarzi, and Adineh H. The effects of Amax yeast fed to Persian sturgeon (Acipencer persicus) larvae via bioenrichment of Daphnia magna. AACL Bioflux 4(3):361-369.

Courtenay WR, Williams JD. 2004. Snakeheads (Pisces, Channidae): A Biological Synopsis and Risk Assessment. Florida: U.S. Geological Survey.

Damanik BH, Hamdani H, Riyantini I, dan Herawati H. 2018. Uji Efektivitas Bio Filter Dengan Tanaman Air untuk Memperbaiki Kualitas Air Pada Sistem 
Akuaponik Ikan Lele Sangkuriang (Clarias gariepinus). Jurnal Perikanan dan Kelautan 11(1): 134-142.

Gastesoupe FJ. 1999 The use of probiotics in aquaculture: a review. Aquaculture 180: $147-165$.

Hemaiswarya S, Raja R, Ravikumar R, Carvalho IS. 2013. Mechanism of action of probiotics. Brazilian Archives of Biology and Technology 56(1): 113-119.

Hernandez LHH, Barrera TC, Mejia JC, Mejia GC, Del Carmen M, Dosta M, De Lara Andrade R, Sotres JAM. 2010. Effects of the commercial probiotic Lactobacillus casei on the growt, protein content of skin mucus and stess resistance of juveniles of the Porthole livebearer Poecilopsis gracilis (Poecilidae). Aquaculture Nutrition 16: 407-411.

Jianguang Q, Fast AW, Kai AT. 1997. Tolerance of snakehead Channa striatus to ammonia at different pH. Journal of the World Aquaculture Society 28(1): 87-90.

Kuhn DD, Boardman GD, Lawrence AL, Marsh L dan Flick GJ. 2009. Microbial floc meal as a replacement ingredient for fish meal and soybean protein in shrimp feed. Aquaculture 296(1-2): 51-7.

Ling Y, Zhang R, Ke C, Hong G. 2018. Effects of dietary supplementation of probiotics on growth, immune responses, and gut microbiome of the abalone Haliotis diversicolor. Aquaculture 493: 289-295.

Lu Q, Han P, Xiao Y, Liu T, Chen F, Leng L, Liu H, Zhou W. 2019. The novel approach of using microbial system for sustainable development of aquaponics. Journal of Cleaner Production 217: 573-575.

Mohammadi F, Mousavi SM, Zakeri M, Ahmadmoradi E. Effect of dietary probiotic, Saccharomyces cerevisiae on growth performance, survival rate and body biochemical composition of three spot cichlid (Cichlasoma trimaculatum). AACL Bioflux 9(3): 451-457.

Manoppo H., Tumbol R. A., Sinjal H. J., Novitarizky I. A., 2019 The use of probiotic isolated from Sangkuriang catfish (Clarias gariepinus var. Sangkuriang) intestine to improve growth and feed efficiency of carp, Cyprinus carpio. AACL Bioflux 12(1):239-245.

Manoppo H, Tumbol RA, Sinjal HJ, and Sumaraw J. 2019. Growth and feed efficiency enhancement by probiotic originating from intestine of carp, Cyprinus carpio AACL Bioflux 12(6): 2188-2194.

Mansyur A dan Tangko AM. 2008. Probiotik: Pemanfaatannya Untuk Pakan Ikan Berkualits Rendah.Jurnal Media Akuakultur 3(2): 145-149.

Marlida R, Suprayudi MA, Widanarni, Harris E. 2014. Isolation, selection and application of probiotic bacteria for improvement the growth performance of humpback groupers (Cromileptes altivelis). International Journal of Science: Basic and Applied Research 16(1):364-379.

Midhun SJ, Arun D, Neethu S, Vysakh A, Radhakrishnan EK, Jyothis M. 2019. Administration of probiotic Paenibacillus polymyxa HGA4C induce 
morphometric, enzymatic and gene expression change in Oreochromis niloticus. Aquaculture 508: 52-59.

Mulyasari, Widanarni, Suprayudi MA, MZ Junior, Sunarno MTD. 2016. Screening of probiotics from the digestive tract of gouramy (Osphronemus goramy) and their potency to enhance the growth of tilapia (Oreochromis niloticus). AACL Bioflux 9(5): 1121-1132.

Nazlia S, dan Zulfiadi. 2018. Pengaruh tanaman berbeda pada sistem akuaponik terhadap tingkat kelangsungan hidup dan pertumbuhan benih ikan lele (Clarias sp.). Acta Aquatica: Aquatic Sciences Journal 5:(1): 14-18.

Nicolae CG, Popa DC, Turek RA., Dumitrache F, Mocuţa D, and Elia E. 2015. Low-tech aquaponic system based on an ornamental aquarium, Scientific Papers: Series D, Animal Science LVIII (2015): 385-390.

Rahmawan MEA, Suminto V, Herawati E. 2014. Application of probiotic into artificial food to improve feed efficiency, growth and survival rate of Dumbo catfish. Journal of Aquaculture Management and Technology 3(4): 257-264.

Saputra F dan Mahendra, 2019, Pemeliharaan pascalarva ikan gabus lokal Channa sp. pada wadah yang berbeda dalam rangka domestikasi. Jurnal Iktiologi Indonesia 19(2): 195-203.

Setiawati JE, Tarsim, Adiputra, dan Hudaidah S. 2013. Pengaruh Penambahan Probiotik Pada Pakan dengan Dosis Berbeda Terhadap Pertumbuhan, Kelulushidupan, Efisiensi Pakan dan Retensi Protein Ikan Patin (Pangasius Hypophthalamus). E-Jurnal Rekayasa dan Teknologi Budidaya Perairan I (2): 151-162.

Sukoco FA, Rahardja BS dan Manan A. 2016. Pengaruh Pemberian Probiotik Berbeda dalam Sistem Akuaponik terhadap Laju Pertumbuhan dan Survival Rate Ikan Lele (Clarias sp.). Journal of Aquaculture and Fish Health 6(1): 24-31.

Sugih FH. 2005. Pengaruh Penambahan Probiotik dalam Pakan Komersil terhadap Pertumbuhan Benih Ikan Gurami. Skripsi. Fakultas Perikanan dan Ilmu Kelautan. Universitas Padjajaran.

Pangaribuan E, Sasanti AD, dan Amin M. 2017. Efisiensi Pakan, Pertumbuhan, Kelangsungan Hidup dan Respon Imun Ikan Patin (Pangasius sp.) yang Diberi pakan bersinbiotik. Jurnal akuakultur rawa indonesia 5(2) :140-154.

Primashita AH, Rahardja BS, dan Prayogo. 2017.Pengaruh Pemberian Probiotik Berbeda dalam Sistem Akuaponik terhadap Laju Pertumbuhan dan Survival Rate Ikan Lele (Clarias sp.). Journal of Aquaculture Science 1(1): 1-9.

Waché Y, Auffray F, Gatesoupe FJ, Zambonino J, Gayet V, Labbé L, and Quentel C. 2006 Cross effects of the strain of dietary Saccharomyces cerevisiae and rearing conditions on the onset of intestinal microbiota and digestive enzymes in rainbow trout, Onchorhynchus mykiss fry. Aquaculture 258: 470-478.

Zega Y, Pamungkas NA, Tang UM. 2018. Effect of Additional Probiotic Bulter Of Multi Cell Water Media With Different Dosage To Decrease Of Amoniak Concentration, Growth And Life Growth Improvements Green Catfish 
(Mystus Nemurus). Jurnal Online Mahasiswa Fakultas Perikanan dan Ilmu Kelautan Universitas Riau 5(2018): 1-14.

Zhou, X and Y. Wang. 2014. Probiotics in AquacultureBenefitss to the Health, Technological Applications and Safety. China: College of Biological and Enviromental Engineering. Gongshang University.

Zonneveld N, Huisman EA, and Boon JH. 1991. Prinsip-prinsip Budidaya Ikan. Jakarta: Penerbit PT Gramedia Pustaka Utama. 